\title{
An Investigation to Language Uses in Mongolian Learners'
}

\section{Third Language Acquisition}

\author{
WU Baiyinna \\ Foreign Languages Institute, Inner Mongolia Normal University \\ Inner Mongolia, Huhhot, China, 010022 \\ Tel: 86-471-2659-045 E-mail: byntnwu@gmail.com
}

\begin{abstract}
In Inner Mongolia Autonomous Region, many Mongolian students are learning English as a third language. In the process of L3 teaching and learning, their mother tongue Mongolian, second language Chinese and target language English are involved. The present paper aims to find out teachers' and students' opinions of the use of the three languages in the third language teaching and learning by Mongolian students at university and the reasons to this phenomenon are discussed. Furthermore, their English learning experience and L2 proficiency are explored. The main findings revealed that Chinese teachers believe that English should be used to the fullest to maintain the maximum use of the target language with the help of Mongolian for the support; however, the majority of Mongolian teachers and Mongolian students believe that Chinese can be used as the main medium instructional language for various reasons, and it is effective to use all the three languages according to the different stages of teaching and the proficiency levels of the three languages.
\end{abstract}

Keywords: Language use, Target language, First language, L2 proficiency, L3 acquisition

\section{The Languages Used in L3 Teaching and Learning of Mongolian Learners}

As English has increasingly become popular in many Asian countries, recently English has been introduced and taught as one of the main foreign languages as one of the educational reforms in Autonomous Regions in China. Therefore, trilingual education has become a new phenomenon of language education in ethnic minority regions in China (Guo Tianxiang, Menggen qiqige and Tang Suge, 2003, pp.48-50). However, in most cases at university in Inner Mongolia, English is mainly taught by Chinese teachers through the learner's L2 Chinese, not by their native language Mongolian. Even some Mongolian teachers themselves are teaching English to Mongolian learners mainly in Chinese, but sometimes some of them do use Mongolian ignoring the fact that, to most Mongolian learners of English, their mother tongue ability is higher than that of their L2 Chinese and L3 English. One of the key reasons is that there are no suitable textbooks written particularly for Mongolian learners of English in Mongolian. Furthermore, the Mongolian teachers were taught English by Chinese teachers using the materials written in Chinese and English when they were students. Therefore, to some extent, they get used to thinking in Chinese, and it becomes easier for them to teach English in Chinese as a main medium language. Even some Mongolian teachers, who can not speak fluent Chinese, are teaching Mongolian learners English in Chinese and English. Mongolian teachers can teach English in Mongolian because there is no policy that they have to teach English to Mongolian learners of English in Chinese in Inner Mongolian Autonomous Region. In brief, three languages are used in Mongolians learner's English teaching and learning process at university with the dominant of the learner's L2 Chinese in most cases.

\section{Literature review}

Recent theoretical and empirical literature has examined issues regarding teachers' uses of L1 and the TL in L2 and FL classrooms, student motivation, exposure to TL input, the appropriate teachers' use of the L1, aiming to promote TL learning at cognitive considerations. Many SL and FL educators insist that it is important for students to be exposed to input in the TL if their motivation is high (Krashen cited in Turnbull, M \& Arnett, K, 2002, p.205), for L2 educators and researchers have long admitted the influence of student motivation on TL learning. However, it has been a hot discussion topic that how much exposure to TL input is optimal from theoretical and pedagogical perspectives. MacDonald (1993) contends that the teachers' maximized use of the TL in the classroom has an influence on student motivation, and relying too much on it may de-motivate students to learn (cited in Turnbull, M \& Arnett, K, 2002, p.206).

However, the use of L1 in the teaching and learning is aimed to make second language learning more efficient. In the language classroom, L1 has been used effectively for various purposes, for instances, the mother tongue can be used as 
a resource for the learners to draw their background knowledge; Most learners prefer to use L1 as an effective learning strategy in the form of translation technique; L1 use can lower the affective barriers to enhance L2 acquisition.

Cook contends that students' L1 can be used as a resource instead of a hindrance to successful learning leading to create more authentic users of the TL. Van Lier (1995, p.38) claims that teachers' use of the learner's L1 helps to promote intake and the teachers can use L1 "judiciously" to facilitate the intake procedure, and the teachers' use of the L1 can provide an enhanced form of input that is more easily processed, and as a result, the learners can understand the TL better. Cognitively, according to Brooks and Donato (1994, p.262) that the learners can use their L1 to convey meaning to and to sustain communication in the TL.

From the preceding related studies on the teachers' uses of L1 and TL, it is commonly believed that it is effective to learn a foreign language through learners' most familiar language which is always their native language in most cases considering intake, while, in terms of providing plenty of TL input, TL can be used. There has been little research studying how learners' L2 can be used in TL learning. However, as far as L3 teaching and learning of Mongolian adults at university in Inner Mongolia are concerned, three languages are involved: Mongolian, Chinese and English. According to Tremblay Marie-Claude (2006, p.109), L2 proficiency and exposure play a significant role in third language acquisition. However, from the theory of recency in third language acquisition, which can have impact on cross-linguistic influence (Cenoz Jasone, 2001, p.8), Chinese is more actively used than Mongolian learners' mother tongue in the teaching and learning in most cases. Therefore, the author conducted a survey with Mongolian and Chinese teachers, and 3 groups of students with different instructional settings to find out the answers to the following: What are the teachers and students attitudes towards the languages used both in the teaching and learning? What is the effective way to teach Mongolian adults English, in their mother tongue Mongolian, or in their TL English, or in their L2, or a combination of any of the three languages? The answers will be discussed based on the results from the questionnaire.

\section{Method}

\subsection{Participants}

The participants in the present study consist of 32 university teachers of English (22 Mongolian, 10 Chinese) and three different groups of 100 Mongolian learners of English who voluntarily answered the questionnaires: Group 1 [Teacher (M)-Lg. (C/M)], Group 2 [Teacher (C)-Lg. (C)], Group 3 [Teacher (M)-Lg. (M)]. Teacher (M) means that the teacher of group 1 is Mongolian, [Lg. (C/M)] means that the main classroom languages for group 1 are Chinese and Mongolian; Teacher (C) means that the teacher of group 2 is Chinese and Lg. (C) means that the classroom language for group 2 is mainly Chinese; Teacher (M) means that the teacher of group 3 is Mongolian and Lg. (M) means that the classroom language used for group 3 is Mongolian. Of all the respondents of the teachers, 10 Mongolian teachers and 10 Chinese teachers are from Inner Mongolia Normal University, 12 Mongolian teachers are from Inner Mongolia College. Mongolian teachers all graduated from Inner Mongolia Normal University, who were taught English by almost all Chinese teachers in Chinese, $73 \%$ have been teaching English less than 5 years, 27\% for more than 5 years, but less than 10 years. The Mongolian teachers are teaching English in Chinese most of the time, and sometimes use Mongolian and English.

Among Chinese teachers, $67 \%$ have been teaching English less than 5 years, 11\% for more than 5 years, but less than 10 years, $22 \%$ for more than 10 years. However, $89 \%$ have been teaching English to Mongolian learners less than 5 years, $11 \%$ for more than 5 years, but less than 10 years. Chinese teachers teach Mongolian learners English in Chinese most of the time and then sometimes use English. There are 100 Mongolian university students who participated in this study, $80 \%$ had learned English to some degree before entering university (See Note 1). Twenty percent didn't learn any English before they came to university.

\subsection{Questionnaires}

There are six questions for group 1 and 2 (See Note 3), nine questions for group 3: Group 1[Teacher (M)-Lg. (C/M)], Group 2 [Teacher (C)-Lg. (C)], and Group 3 [Teacher (M)-Lg. (M)]. There are seven questions for Mongolian teachers and six for Chinese teachers (See Note 2) to collect background information about Mongolian learner's L2 proficiency, the years of teaching/learning English, the languages the Mongolian students expect their teachers to use, and the languages the teachers use in English class, the percentages of the languages the teachers use for one class. (See Appendix $1 \& 2$ )

\section{Results}

The questionnaire asks the participants' background information on the languages the teachers use in Mongolian learners' English teaching, the languages the Mongolian learners expect their teachers to use in teaching, the participants' English learning experience, Mongolian learners' L2 proficiency and University Entrance Chinese score. In the following section, the results will be summarized briefly. 


\subsection{The Teachers' Use of Languages}

Of the 10 Chinese teachers, $85 \%-90 \%$ used Chinese, and 10\%-15\% used English when they taught English to Mongolian learners. Among 22 Mongolian teachers, the mean percentages of the languages they used in English teaching were: $66 \%$ Chinese, $22 \%$ English and 12\% Mongolian, and four of them didn't provide the exact numbers, but the answers were that they used Chinese mostly, sometimes Mongolian and seldom English. Furthermore, three participants said that they didn't use Mongolian, and two said that they didn't use any English.

\subsection{The Language(s) the Mongolian Learners Expect Their Teachers to Use}

As shown in figure 1, 36\% of the participants want to learn English in Chinese, and 13\% of them prefer learning English in Mongolian and Chinese, 20\% of them say that they like to learn English in Mongolian (most of them are from group 3). Group 3: [Teacher (M)-Lg. (M)]. Therefore, it is interesting to find out that the percentage of the Mongolian learner's preference to learn English in Chinese or Chinese and Mongolian is bigger than that in Mongolian. In other words, the participants in the present study prefer learning English through their L2 or the combination of their L1 and L2. This phenomenon needs to be discussed further.

\subsection{The Mongolian Learner's English Learning Experience}

Group 1: the teacher is Mongolian, but mainly uses Chinese for classroom language with some Mongolian; Group 2: the teacher is Chinese and mainly uses Chinese as a classroom language; Group 3: the teacher is Mongolian and uses Mongolian mainly as a classroom language.

A few years ago, there were few students who had learned English when they came to university, but recently English has been introduced in Mongolian middle schools, although they are not required to take English test in the university entrance exam. However, as revealed in Figure 2, $80 \%$ of the three groups of the participants had the learning experience of English, to some degree, before they came to university, which was not predicted.

\subsection{Mongolian Learners'L2 Proficiency}

As can be seen in Table 1, the highest mean score is 121 from group 2 with the teacher Chinese, who mainly uses Chinese as a classroom language. The lowest one is 109 from group 3 with the Mongolian teacher teaching mainly in Mongolian. Group 2 is in the middle.

Table 2 presents the SPSS output of one-way ANOVA of three group learners' L2 proficiency, showing that the F value was significant at a .001 level, and from the Post Hoc Tests, it is clear that between group 1 and 3, group 2 and 3 , their University Entrance Chinese Score is significantly different at .032 and 0.001 respectively. To summarize this analysis, it is obvious that there are differences in the L2 proficiency among the three groups.

\section{Discussion}

According to the related studies, it is effective for L2 learners to learn the TL in their mother tongue. In most cases, SL learners' mother tongue ability is higher than any other languages they know, although there are obviously some exceptions. However there is little research studying how to use learner L2 and what extent the learners L2(s) should be used in the TL acquisition. Therefore, in the present study, the questionnaire was designed to investigate what language(s) the teachers use and what language(s) the learners expect their teachers to use in Mongolian learner's L3 teaching and learning, and gather the participants' background information of English learning experience and their Chinese language competence.

The results indicate that the Chinese teachers use Chinese more than $85 \%$ of the time, and of the Mongolian teachers, $66 \%$ use Chinese. However, for $10-20 \%$ of the time, they use English to teach Mongolian learners English. Only around 10\% Mongolian is used, and three teachers said that they did not use Mongolian at all. It can be concluded that the Mongolian learners are learning English through their L2 Chinese most of the time and Mongolian is used very seldom at the universities in which the questionnaire was conducted.

The Mongolian students are learning English in Chinese are because there are not enough Mongolian English teachers, and the Mongolian teachers are also teaching English to Mongolian learners in Chinese most of the time. The reasons are first the Mongolian English teachers, they themselves learned English in Chinese and used the materials written in Chinese, so to some extent, they get used to thinking in Chinese and using Chinese, and it is easier for them to teach in Chinese. Second they have the ability to teach in Chinese. Third they lack the supplementary materials written in Mongolian to support their teaching. As revealed in figure 1, around half of the Mongolian learners responded that they expected their teachers to use Chinese (36\%), or Chinese and Mongolian (13\%), or either Chinese or Mongolian in their English class (13\%). This finding is different from the research done at Nara Educational University (Goihan, 2005). Her findings indicate that most of the participants prefer learning English in Mongolian and using the materials written in Mongolian. One of the possible reasons caused the different result is that some of her subjects were from Huhhot Mongolian Middle school, therefore, some of the subjects' Chinese ability was not good enough to understand English lessons in Chinese, especially those who just came from remote and pastoral area, particularly from western 
part of Inner Mongolia.

Some of the possible reasons that most of the participants in the present study want to learn English in Chinese are most of the Mongolian learners at university do not seem to have much difficulty in understanding the English lesson in Chinese, since they have already learned Chinese for nine years starting from their third year at elementary school with a lot of input and exposure living. There are many chances for most of the Mongolian students to use and practice Chinese outside of the classroom, which is quite different from the learning environment in which English is learned. It seems that some students get used to the way of teaching in Chinese when they began to learn English at middle schools. Finally, another key reason is that they want to improve their Chinese language ability, and most of them agree that it is very important and necessary for Mongolian learners to improve Chinese for further study or getting a better job after their graduation. It is true that they sometimes have to challenge Han Chinese students for going to post graduate school or getting a better work position.

Mongolian students begin to learn Chinese from their third year at elementary school and they have already had nine years experience of learning Chinese when they come to university. However, their level of Chinese is varied, which is confirmed by the result of one-way ANOVA of the three group learners' University Entrance Chinese Language score. So the students with different L2 proficiency level have different perceptions on the languages used in their teaching and learning.

From the above discussion, there are obvious different beliefs between Mongolian teachers and students, and Chinese teachers. Most of the Chinese teachers think English should be taught in Mongolian and English, not including Chinese, for Mongolian is the learners' mother tongue, which is better than their Chinese because they do not quite understand Mongolian students' Chinese ability, and English should be used thinking of providing learners as much input as possible. While most of the Mongolian teachers and students propose that the three languages should be used for instruction and developing materials because Mongolian teachers share the same experience of learning English with the Mongolian students in this study.

\section{Conclusion}

The study reveals what beliefs teachers and students have about the key factor: language uses in the third language teaching and learning. It seems to be effective to use Mongolian or Chinese or a combination of Chinese and Mongolian at the beginning stages regarding better intake and step by step, the amount of the using English can be increased for the input perspective. It is very essential to consider carefully the amount of English use in Mongolian learner's English learning, for on the one hand, the teachers' maximized use of the TL in the classroom has an impact on student motivation, and is perceived as a chance to give students maximum exposure to the target language and on the other hand, relying too much on it may cause de-motivation to students. Furthermore, considering making good use of the learners previously learned knowledge: their L1, especially the L2 Chinese should be used for the support to L2 acquisition. To what extent the languages should be used, depend on the proficiency levels of the languages, the stages of the teaching, the nature of the course and the goal of the task. All those factors should be taken into account in using the three languages involved in the third language acquisition of Mongolian students in multilingual contexts in China. The implication of the present study provides some ideas regarding language uses in other four Autonomous Regions in China.

\section{References}

Brooks, F. \& Donato, R. (1994). Vygotskian Approaches to Understanding Foreign Language Learner Discourse during Communicative Tasks. Hispania, 77, 262-274.

Cenoz Jasone. (2001). The Effects of Linguistic Distance, L2 Status and Age on Cross-linguistic Influence in Third Language Acquisition. Cross-linguistic Influence in Third Language Acquisition: Psycholinguistic Perspective , $8-10$.

Goihan. (2006). An Effective English Language Teaching that Contributes to Ethnic Minority Education in Inner Mongolia, China. A Thesis Presented for Partial Fulfillment of the Requirements of Master Degree of Education.

Guo Tian xiang, Meng gen qi qi ge, Tang Suge. (2003). Considerations on the Reform of Bilingual and Trilingual Teaching in Inner Mongolia. Journal of Inner Mongolia Normal University. Vol.15, No.1, 48-50.

Poulisse Nanda and Bongaerts Theo (1994). First Language Use in Second Language Production. Applied Linguistics 15/1, 36-57. Oxford University Press.

Tremblay Marie-Claude. (2006). Cross-linguistic Influence in Third Language Acquisition: The Role of L2 Proficiency and L2 Exposure. CLO/OPL, Vol.34, 109-110.

Turnbull, M \& Arnett, K. (2002). "Teachers' uses of the Target and First Language in Second and Foreign Language Classrooms." Annual Review of Applied Linguistics 22, 204-218. 
Van Lier, L. (1995). The Use of the L1 in L2 Classes. Babylonia, 2, 37-43.

\section{Notes}

Note 1. Some learned one year at junior middle school, some learned for two years, but some learned one year at Senior high school, but some learned six years from junior middle to senior high school. Some only learned a few words, and some sentences.

Note 2. Question No.7 is not included in the questionnaire for Chinese teacher.

Note 3. The questions 4, 5, and 6 are not included in the questionnaire for Group 1 and Group 2 students.

\section{Appendices}

\section{Appendix 1: Questionnaire for the teachers}

Please answer the following questions.

1. How many English teachers are there at your school?

2. How many Mongolian English teachers are there at your school?

3. How many years have you taught English?

4. How many years have you taught English to Mongolian learners?

5. What languages do you use when you teach English to Mongolian learners?

6. What is the approximate percentage of the language(s) you use in one lesson when you teach English to Mongolian learners?

7. If you use Mongolian when you teach English to Mongolian learners, when do you use it? (note 2)

\section{Appendix 2: Questionnaire for the students (Translated Version)}

Please answer the following questions.

Grade:

Age:

Sex:

1. Where are you from?

2. Did you learn any English before you came to university? yes/no

3. When did you begin to learn English? How long have you learned?

4. Have you learned English in Chinese? Where and how long did you learn? (Note 3)

5. Are you learning English in Chinese somewhere else?

6. When does your English teacher use Chinese in your English class? What is the approximate percentage of the use of Chinese?

7. What language(s) do you want your English teacher to use to teach you?

8. What is the purpose of your English learning?

9. What is the score of your Chinese University Entrance Exam? 
Table 1. Statistics for the participants' University Entrance Chinese Exam Score

\begin{tabular}{|c|c|c|c|c|}
\hline & & Group1 & Group2 & Group3 \\
\hline \multirow[t]{2}{*}{$\mathrm{N}$} & Valid & 46 & 31 & 19 \\
\hline & Missing & 53 & 68 & 80 \\
\hline Mean & & 114.6087 & 121.0645 & 109.6842 \\
\hline Std. Error of Mean & & 1.79626 & 1.40425 & 2.09992 \\
\hline Median & & 115.0000 & 121.0000 & 106.0000 \\
\hline Mode & & 115.00 & 120.00 & $103.00(a)$ \\
\hline Std. Deviation & & 12.18283 & 7.81851 & 9.15334 \\
\hline Variance & & 148.421 & 61.129 & 83.784 \\
\hline Skewness & & -1.059 & -.652 & .702 \\
\hline Std. Error of Skewness & & .350 & .421 & .524 \\
\hline Kurtosis & & 1.762 & 1.056 & -.457 \\
\hline Std. Error of Kurtosis & & .688 & .821 & 1.014 \\
\hline Range & & 62.00 & 38.00 & 32.00 \\
\hline Minimum & & 76.00 & 100.00 & 96.00 \\
\hline Maximum & & 138.00 & 138.00 & 128.00 \\
\hline Sum & & 5272.00 & 3753.00 & 2084.00 \\
\hline
\end{tabular}

Table 2. One-way ANOVA of the three group learners' University Entrance Chinese Exam score

\begin{tabular}{|l|l|l|l|l|l|}
\hline & $\begin{array}{l}\text { Sum } \\
\text { Squares }\end{array}$ & of & Mean Square & F & Sig. \\
\hline $\begin{array}{l}\text { Between } \\
\text { Groups } \\
\text { Within Groups }\end{array}$ & 1634.473 & 2 & 817.237 & 7.584 & .001 \\
Total & 10020.933 & 93 & 107.752 & & \\
\hline
\end{tabular}

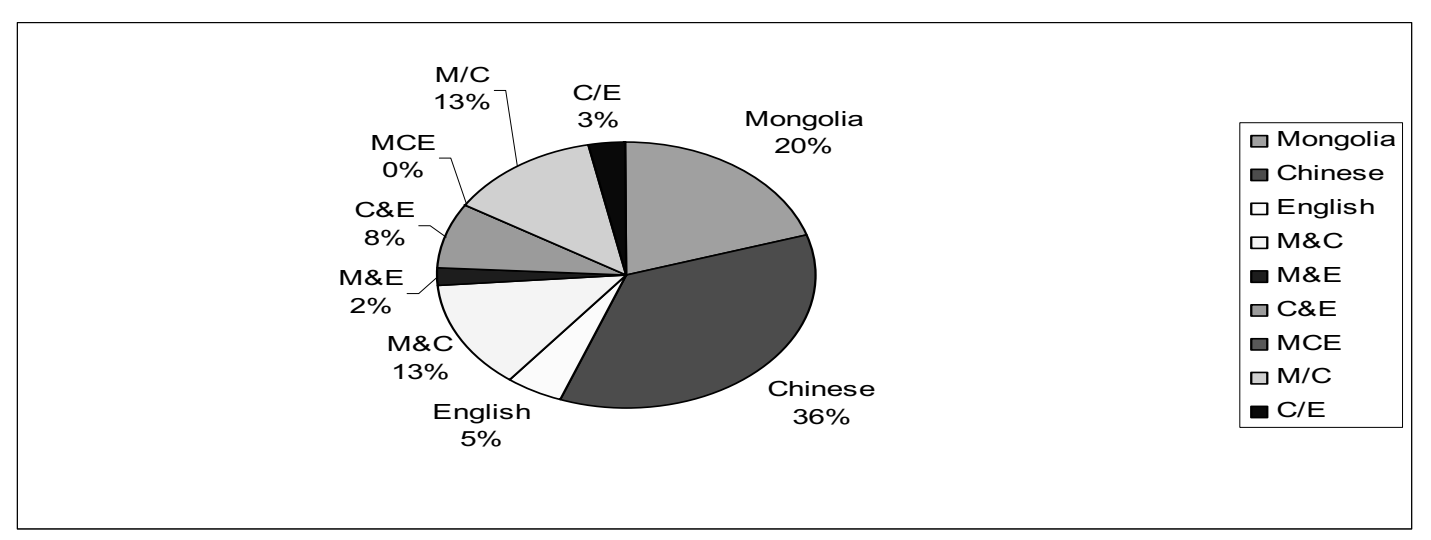

Figure 1. The percentages of the participants' preference of the languages they expect their English teachers to use 


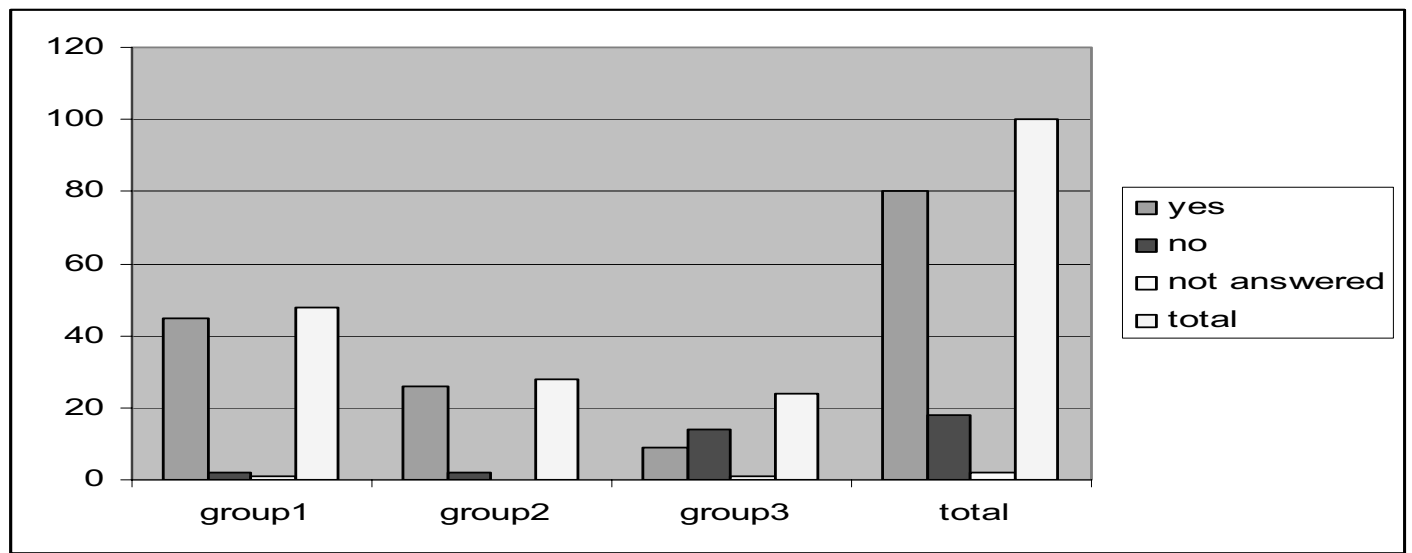

Figure 2. The three groups of learners' learning experience of English before entering university 